\title{
Need Assessment of Stunted Children During Pandemic Covid-19 to Develop Nutrition Intervention Program in Jember District, East Java, Indonesia
}

\author{
Dhyani Ayu Perwiraningrum* \\ Clinical Nutrition Program Study, \\ Health Departement \\ Politeknik Negeri Jember \\ Jember, Indonesia \\ dhyani@polije.ac.id \\ ORCID: 0000-0002-3755-730X
}

\author{
Alinea Dwi Elisanti \\ Clinical Nutrition Program Study, \\ Health Departement \\ Politeknik Negeri Jember \\ Jember, Indonesia \\ alinea@polije.ac.id \\ ORCID: 0000-0003-1270-6281 \\ Agustina Endah Werdiharini \\ Clinical Nutrition Program Study, \\ Health Departement \\ Politeknik Negeri Jember \\ Jember, Indonesia \\ agustina_endah@polije.ac.id
}

\author{
Dahlia Indah Amareta \\ Clinical Nutrition Program Study, \\ Health Departement \\ Politeknik Negeri Jember \\ Jember, Indonesia \\ dahlia_amareta@polije.ac.id \\ ORCID: 0000-0003-1495-0149
}

\begin{abstract}
The COVID-19 pandemic makes it possible for increasing the number of stunted children in Jember. So it is difficult to predict the target to reduce stunting. Jember is one of the districts in East Java Indonesia, has a fairly high number of children under five $(80,359$ people). This study aims to examine the need for developing a nutritional intervention to overcome stunting during COVID-19 in Jember district. This study is a descriptive-analytic study with a qualitative approach in the case of stunting in Jember district. The research was conducted in 4 sub-districts in Jember. The research target of families who have children under five with stunting, the risk of stunting and stakeholders. Data analysis used Precede Proceed theory with five diagnostic phases. The social diagnosis phase describes the quality of life in Jember. The epidemiological diagnosis phase describes the status of the Covid area. The Behavior and environment diagnosis phase describe there is no direct anticipation of COVID-19. The educational and ecological diagnostic phase examines behavior in child care, low purchasing power and access to food availability, policies and sanitation. Administrative and policy diagnosis phases, describe about funds, the lack of covid 19 information and limited health resources in the region.
\end{abstract}

Keywords-COVID-19, need assessment, stunting, nutrition intervention, children under five

\section{INTRODUCTION}

Malnutrition is still an unresolved problem in Indonesia, one of which is stunting. Stunting is a condition of height according to the child's age below the median standard of the child's growth curve [1]. Nationally, the proportion of very short and short toddlers reaches $30.8 \%$ [2]. The determinants factors affected stunting in children are family income, maternal nutritional knowledge, child care practices, history of infection, immunization, protein intake, and mother's education. Meanwhile, the impact of stunting on achievement based on research shows that stunting primary school children have low academic achievement. The higher the stunting rate, the lower the academic achievement of elementary school children [3]. Several efforts to reduce the prevalence of stunting have been carried out by the government, through several flagship programs in almost every ministry, one of which is the ministry of health's program, namely screening for Chronic Energy Deficiency (CED) in pregnant women, providing nutritional supplementation through giving $\mathrm{Fe}$ tablets and additional food to mothers. Giving complementary foods to children under five with a risk of malnutrition. However, some of these stunting prevention measures cannot run optimally during this pandemic. Early detection such as routine growth monitoring in health facilities which is important in preventing malnutrition in children cannot be facilitated. While children can suffer from chronic malnutrition and become stunted without prompt treatment.

Jember is one of the districts in East Java Indonesia, has a fairly high number of children under five ( 80,359 people). In the 2018 years, has recorded the only 49 PHC in Jember District. The ratio of this health service has 1 PHC: 48,000 people. This condition will give impact on health service disparity. Ideally, Jember District should have 80 PHC of 2.3 million people. According to UN estimates, COVID-19 triggers the threat of stunting worldwide, so nutrition intervention management in stunting also needs to consider for preventing COVID-19 in the community. To develop comprehensive, bottom-up, and right on target intervention models for stunting during the COVID-19 pandemic, very important to carry out an assessment needs 


\section{RESEARCH METHOD}

This research is a descriptive analytic with cross sectional design using a qualitative approach in the form of a case study. The case study in this research analyzes the incidence, phenomenon, or social situation of stunting cases in Jember district. The research was conducted in sub-districts with different characteristics, namely plantation areas (Silo subdistrict), agricultural areas (Sumberbaru subdistrict), coastal areas (Puger subdistrict), and urban areas (Sumbersari subdistrict). The sampling technique used a combination of purposive and snowball sampling. Data was collected through the triangulation method, in-depth interviews, online focus group discussions (FGD), participatory observation and document review [12].

The research targets are families who have children under five with stunting or the risk of stunting, stakeholders, namely representatives of the Health Office, the Village Community Empowerment Service (VCES), Districts and Villages as informants. In-depth interviews were conducted with 8 key family informants with under five (children under five years) stunting and at risk of stunting. Informant interviews, FGDs were conducted online. The data analysis used a study of change modification theory to develop a health planning model, namely, Precede Proceed with five diagnostic phases (social, epidemiological, behavioral and environmental, education and ecological, administrative and policy) [5] in developing health programs in the form of nutritional interventions.

Data analysis is based on the results of key informant interviews and FGD by analyzing any information absorbed by the researcher. The research instrument used topic guides, checklists and coding and transcript categorization to identify themes. The case study research analysis consists of three main lines including data reduction, data presentation and conclusions [12]

\section{RESULT AND DISCUSSION}

\section{A. Social Diagnosis Phase}

Health status is a causa of quality of life, by looking at the determinants behind it. This social diagnosis phase helps the community to assess the quality of life from various sides $[4,10]$. Social diagnosis is carried out by starting with the question "What is the quality of life like today? What has been achieved and what is the background?". This study conducted a situation analysis in four regions with different characteristics in the Jember Regency area. Secondary data is sourced from the District Health Profile and Public Health Center (PHC) in 2020.

Meanwhile, the study is directed at the Regional Medium Term Program Plans 2016-2021 and Jember Regency Health Budget. Increasing community nutrition, environmental and family health awareness are part of the 8 Health Development Policy Directions. Regional Expenditure Budget (REB) 2019 of Jember for District Health Office reach 14\%, $18 \%$ for Indirect Expenditures (salaries and allowances) $82 \%$ Direct Expenditures (programs / activities). Specifically for the Maternal and Child Health program, $0.4 \%$ of the Health Office program budget 2019 was allocated and only about $14 \%$ of the program budget was allocated for preventive activities [13]. In 2020, Jember Regency refocused the budget for Covid 19 (amounting to 479.4 billion) on 7 April which was later revised by the Joint Decree of the Minister of Home Affairs and the Minister of Finance on April 9, 2020, namely Letter number 119/2813 / SJ and Number 177 / KMK.07 / 2020 containing the acceleration of the adjustment of the 2020 FY REB for handling COVID-19, as well as safe guarding people's purchasing power and the national economy. This $2 / 3$ budget size is focused on handling health due to COVID-19 [14]. The quality of life of the informants explained that poverty causes them to be unable to choose a quality of life that is better than what they currently get13. The average family of stunting and at risk of stunting in children under 5 years has an income below the Regional minimum wage (RMW) of Jember (IDR 2,355,000 in 2020) [15].

"I don't give my child anything, sometimes I can eat up to three times a day, thank goodness, but that's rare, because we're just small people" (Informant 3, Sumberbaru)

"If a day is enough for the family (5 people) at most ... at most 2 times the side dishes are also taken from the garden, my results are just farm laborers, not really enough, if the RMW is people in the city, the rich one" (Informant 6, Silo)

"If it's like this Corona, it's the same, we are still looking for hard meals. Especially now that a lot of people are online, they spend a lot to buy cellphone credit, can buy cellphone credit but can't eat ... hahahaha (laughing)" (informant 5, Puger)

"If the choice is looking for what to eat at home for fear of illness, yes I choose to look for food, how can you live without eating ..?" (informant 5, Puger)

In addition, the level of education that exists in families of children under five is generally elementary school, the highest is only junior high school, because there are many early marriages where there is an opinion that people in the research area will become old maids when they don't get married, while for men they must immediately working to earn a living for family life, school is not a top priority.

"I married at 13, at 15 I already have children ... instead of becoming an old maid, if people say, I better get married now" (Informant 7, Silo)

During the pandemic, several health centers have initiated home visits to replace the posyandu, but due to the increasing number of Covid 19 cases, this activity has not been carried out regularly.

"Usually there are posyandu, but because of the pandemic it cannot be held, moreover there are groups of people. So yes ... cadres go to the homes of toddlers" (Cadre Informant, FGD Sumbersari)

"To go to the toddler's house, you usually have to wear the correct equipment, try not to have too much contact with other people ... yes, for our safety, also the safety of the toddler. Sometimes I get confused about having to go around, even though it's important to monitor toddlers .. " (Cadre Informant, FGD Silo) 


\section{B. Epidemiological Diagnosis Phase}

Based on the research, information was obtained that the condition of the research area (Silo, Sumberbaru, Sumbersari, Puger) where children are stunted and at risk of stunting, are areas with red and orange zones (June) [9]

Researchers get information related to specific health problems at the research location. Most of the informants admitted that the COVID-19 problem was a double burden for their lives. Specific health problems that contribute to the quality of life for families with stunting and at risk of stunting are a big risk for COVID-19, because of the inability to anticipate the transmission of covid in their families and their environment.

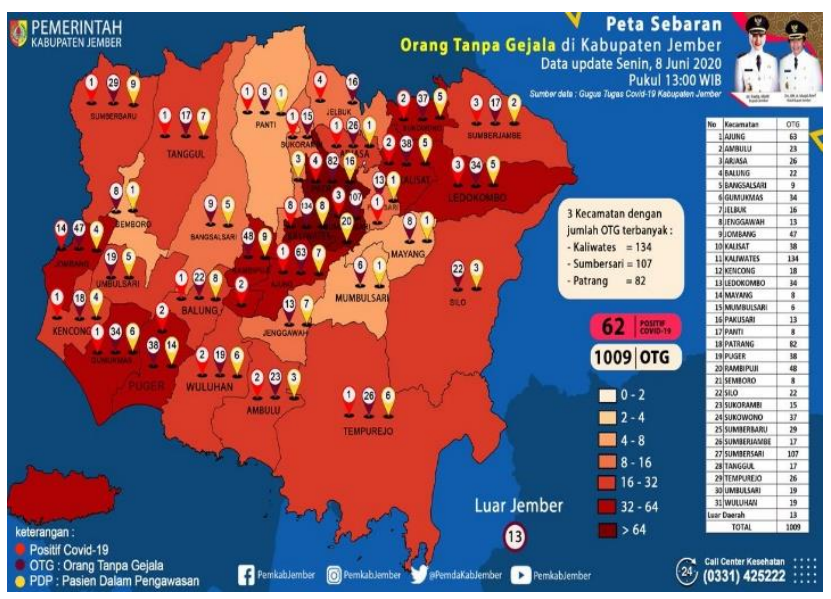

Fig. 1. Distribution Map Covid zones in Jember, East Java, Indonesia for June 2020

"Yes, if we are sick, we just give up, because we don't have anything" (informant 3, Sumberbaru).

"The hard thing is to make money, now it's hard, mb, if you don't come close to people, the child is sick like this (the risk of stunting) is already heavy, especially when there is a corona" (Informant 2, Sumbersari)

This statement was strengthened by the results of the FGD with stakeholders from the PHC and District.

"Currently we are fighting against COVID-19, because of its rapid spread, we must anticipate all possibilities ... but those who are sorry for the lower class people, on average, do not understand the dangers of COVID-19, even they tend to be helpless, especially poor families. . On average, family children under five have very poor nutritional intake, that's why there is a lot of risk of stunting, because of COVID-19, they suffer more and more, making it difficult to find food, let alone supplement with adequate nutrition for children" (PHC informant, FGD Sumbersari).

"Stunting can exacerbate COVID-19 sufferers, if there are children who are affected" (PHC Informant, FGD Silo)

LIPI revealed that the problem of child nutrition is one of the risks of socio-economic impacts on children caused by the COVID-19 pandemic. As many as 24 million children under five are at higher risk of experiencing malnutrition or malnutrition [7]. There is a relationship between child care behavior and belief in Covid 19. There are still many mothers or caregivers of toddlers who do not pay attention to hygiene when caring, especially when feeding toddlers. Toddlers are also often invited to do activities together outside the home, such as buying vegetables at shopping places with lots of people, or hanging out with neighbors without applying social / physical distancing. The results of the FGD showed that COVID-19 was believed to be like an ordinary disease.

\section{Behavioral and Environtment Diagnosis Phase}

The behavioral and environmental diagnosis phase identifies health problems based on causes including behavior and non-behavior [4.5], diagnoses obtained in the form of behavioral and non-behavioral needs in stunting during the Covid19 pandemic that need to be resolved through nutritional interventions.

The information obtained in the study focuses on the double burden that stunting families face and the risk of stunting during the Covid 19 pandemic. In families of toddlers stunting and at risk of stunting can not anticipate the risk of covid19 transmission appropriately. It is shown that there is no immediate anticipation of Covid 19 and does not yet understand the family about Covid and its impact. Based on FGD results, there are still many families with toddlers who always take their children out of the house without using masks or personal protective equipment from Covid 19.

\section{"It's a good place to stay." (Cadre informant, FGD Sumberbaru)}

"The toddler is often brought to work, yes because it is forced because no one is looking after... But the pity if you meet people, do not wear masks.." (Cadre informant, FGD Sumbersari)

According to observations, the average community is still very easy to gather without applying social/phisical distancing. From four different research sites, Sumbersari is a densely populated urban area and most often exposed to Covid 19 prevention information, but in general there are still many people who have not implemented social/phisical distancing appropriately, namely keeping a safe distance when in contact with others between 1-1.5 meters and using personal protective equipment.

While other locations such as Silo, Puger and Sumberbaru generally do not distinguish the activity carried out during pandemics or normal.

"The average person here does not understand the application of social distancing, if meeting family or friends, such as in a coffee shop there is also no distance.." (PHC Informant, FGD Puger)

\section{" it seems that there needs to be a socialization of healthy clean living behaviors (PHBS) here and wash your hands with soap that can really change behavior.... if such information has been attempted, but still minimal application" (PHC Informant, FGD Sumberbaru)}

Through in-depth interviews with the Office related to the anticipatory behavior of the community towards Covid19, many people are less understanding and less aware of the importance of PHBS to be applied daily such as when entering 
the house, preparing to leave the house, when eating and interacting with children and toddlers.

\begin{abstract}
"Information related to covid19 prevention has actually been widely genic, but behavior is still unchanged, this is causing still high covid19 events in Jember. Many are less aware that PHBS is very important, if we want to enter the house yes must immediately change clothes, wash hands using soap, especially if there are toddlers or babies, right they are more susceptible to disease. Sometimes people like to feed toddlers by hand, but don't wash their hands..." (Health Service Informant, Jember)

"Villagers still have the presumption of Covid 19 is only in big cities and on $T V$, so it is very difficult to tell how to interact with others. In normal life alone, the problem of healthy clean living behavior is not very important, nowadays it is still considered so" (VCES Informant, Jember)
\end{abstract}

"if it is difficult to wash hands with soap, maybe in places of gathering people should be provided a means of hand washing with the correct instructions.... so far there have not been many facilities" (Cadre informant, FGD Puger).

\section{Education and Ecological Diagnosis Phase}

The education and ecology diagnosis phase describes factors that can help or can actually inhibit positive changes in behavior and the environment and are targets between or objectives of the program. This phase identifies behavioral and environmental conditions that are health status or quality of life by taking into account the causative factors then things should be changed. These factors are identified as predisposing factors; enabling and reinforcing[5].

The results revealed that there is a link between toddler parenting behavior and confidence in Covid 19. From the observations it is known that there are still many mothers or caregivers of toddlers who are less concerned with cleanliness when parenting toddlers and when giving food to toddlers. In addition, toddlers are often invited to do activities together with caregivers, such as buying vegetables in a large shopping place, or gathering with neighbors without applying social/phisical distancing.

From the results of FGD obtained that covid 19 is believed to be like a common disease that can still be cured.

"Corona is considered like a common cold and cough .." (PHC informant, FGD Sumbersari)

"Corona is not here, only in the city, there are still many who think that ..." (PHC informant, FGD Silo)

Predesposium factors include behavior in toddler care.

"I don't know what to do when dealing with Corona, sometimes I can just eat. I'm grateful ... if a child is sick like this, I find it difficult because I don't know what to do" (informant 1, Puger)

The public lacks correct and accurate information regarding COVID-19.

"Yes, I know that the corona is contagious (like the flu) ... I wear a mask but yes, I use it at home, I use it many times, I don't know if the mask is also disposable, it must be washed immediately ... I don't understand this. before .. "(informant 8, Sumberbaru)

Meanwhile, related to other supporting factors in the form of personal hygiene facilities such as facilities

"Wash your hands at most in a well or in a jedding (bathroom), if in a public place there are no ingredients here" (Informant 4, Silo)

"The water here comes from sources, if the facilities are still not accessible, especially from remote areas" (VCES informant, Jember)

Enabling factors include purchasing power and access to low food availability, policies for implementing social distancing, sanitation and clean water facilities that are difficult to reach, and information is confusing.

"If there is food, it is shared by everyone in the family ... the children too" (informant 4, Silo)

"Usually the mother (grandmother) cooks, the children also, I only feed the child if the child wants to eat" (Informant 2, Sumbersari)

"If you don't want to eat, what do you do, if you are forced to continue to do so you can't enter the food .." (Informant 1 , Puger)

Care during the COVID-19 pandemic, families with children under five are stunted and at risk of stunting, did not differentiate between during the pandemic or not. Toddlers are generally cared for by the mother, because the average mother is at home, toddlers are still invited to do activities, without using PPE. FGD related to policies, it was revealed that there were still many rules and restrictions that were violated by the community due to limitations in fulfilling their daily needs.

"Actually the rules already exist, they have been socialized, but the people don't want to know ..." (VCES Informant, Jember)

"If you follow the rules it could be not ... but who gave us food ...?" (informant 7, Silo).

Reinforcing factors include social support for the quality of children's nutrition, quality of care during the pandemic and strict application of regulations related to Covid 19.

\section{E. Administrative and Policy Diagnosis Phase}

Support for health is obtained from an allocation of $20 \%$ of the village fund (Village Fund Budget) for handling health problems in the region, including stunting and COVID-19 [11]. However, the utilization of village fund budgeting is determined by the activities selected as well as the policies taken at the village level relating to priority activities. The budget for stunting and COVID-19 does not have separate portions, so they overlap.

"Stunting is a priority program for village fund budgeting, but the policy of refocusing on COVID-19 also puts a burden on the health budget of each village ... so that it can overlap which first needs priority" (Health Service Informant, Jember).

"Public Integrated Service (Posyandu) is currently being replaced by home visits, there are many cadres, but only 
a few can actually measure toddlers, while there are quite a few toddlers who need monitoring ... this is a problem too, many toddlers are not reachable either because of the location of their residence. as well as the limitations of cadres to take measurements ... "(Cadre informant, FGD Sumberbaru).

The results of the study also revealed that there was a lack of socialization on COVID-19, especially for mothers with toddlers to prevent the severity of stunting. So far, socialization has mostly focused on restrictions, not a solution to dealing with COVID-19.

"There is a lot of information about Corona, but there is no solution for mothers how to deal with the corona and prevent stunting at once .." (Cadre informant, FGD Sumbersari)

Analysis of community needs is an important component in the planning and provision of health [8]. If the needs analysis is neglected, there are many less relevant approaches applied in society, especially in overcoming the crucial problems that arise [6]. Needs analysis becomes evidence based on further program development.

According to Green and Kreuter [5] community empowerment programs require a comprehensive understanding of community health needs, active community participation, use of existing local resources, the participation of local stakeholders in identifying problems and combining several strategies to intervene.

Based on Health Ministy survey, at 4798 health centers in Indonesia, there are several indicators that show the potential for increased stunting during COVID-19. It is known that there is a decrease in Integrated service post (ISP) activities, as many as 43.51 percent of ISP stopped their activities during the pandemic, 37.23 percent experienced a decrease in activities, and 18.70 percent of ISP was carrying out activities like normal conditions. Then, as many as 30.58 percent of pregnant women were known not to have visited the health center, as well as 31.01 percent of children under five with stunting / malnutrition [7.8].

This has implications for an increase in stunting cases during the COVID-19 pandemic [13]. Other several indicators such as decreased income and expenditure or power, public purchases, and social restriction policies also play a role in influencing stunting rates. However, nutrition problems should remain a priority for the government. The COVID-19 pandemic must not reduce government efforts to ensure adequate nutrition for the community.

\section{CONCLUSION}

The analysis of needs for five phases of diagnosis, namely social diagnosis, epidemiology, behavior and environment, education and ecology, administrative and policy in developing health programs. The social diagnosis phase describes the quality of life in Jember. The epidemiological diagnosis phase describes the status of the Covid area. The Behavior and environment diagnosis phase describe there is no direct anticipation of COVID-19. The educational and ecological diagnostic phase examines behavior in child care, low purchasing power and access to food availability, policies and sanitation.Administrative and policy diagnosis phases, describe about funds, the lack of covid 19 information and limited health resources in the region. Suggestion: The need to consider the needs that exist in society through a needs analysis.

\section{REFERENCES}

[1] D.Onis., Mercedes, M.Blossner, and World Health Organization. "WHO global database on child growth and malnutrition". No. WHO/NUT/97.4. World Health Organization. 1997.

[2] Ministry of Health of the Republic of Indonesia, Key Results of RISKESDAS 2018. "Health Research and Development Agency Republic of Indonesia", Jakarta, Indonesia. 2018.

[3] Picauly, Intje, and SM. Toy. "Determinant analysis and the influence of stunting on school children's learning achievements in Kupang and East Sumba, NTT." Journal of Nutrition and Food 8.1 (2013): 55-62. 2013.

[4] Manitoba Health. "Community health needs assessment guidelines". Manitoba Health. Online book chapter.1997. [http://www.manitoba.ca/health/rha/chnag.pdf].1997.

[5] LW.Green dan MW.Kreuter. "Health Program Planning: An Educational and Ecological Approach", 4th Edition. McGraw-Hill, New York. 2005

[6] ES.Suleman, et.al.. "Application of PRECEDE-PROCEED Model in Community Empowerment Program Planning in Health Sector Based on Assessment of Public Health Needs", Yarsi Medical Journal, Yogyakarta.2015.

[7] Kompas. "In addition to the COVID-19 Pandemic, Indonesian Children Also Face Stunting". In Press. Source: https://www.kompas.com/sains/read/2020/07/11/200400823/selainpandemi-COVID-19-anak-indonesia-juga-menghadapistunting?page $=$ al. , 2020.

[8] Winahyu, AI,. "COVID-19 Pandemic Potentially Threatens Stunting Reduction Targets". In Press. Source: https://mediaindonesia.com/read/detail/342872-pandemiCOVID-19-berpotensi-ancam-target-penurunan-stunting (Access Sept. 2020) 2020.

[9] Jember Gov. "Distribution Map and Covid-19 Monitoring Data of Jember Regency" Source:https://www.facebook.com/jemberkab/posts/peta-sebarandan-data-pantauan-COVID-19-di-kabupaten-jember-per-senin-25mei-202/2869593083096562/ (Access Sept 2020) 2020.

[10] RE.Black, CG. Victora, SP. Walker, et al. "Maternal and child undernutrition and overweight in low-income and middle-income countries". Lancet 2013; 382: 427-51. 2013

[11] Ministry of Health of the Republic of Indonesia. "Guidelines for The Use of Village Funds for Health" Source: https://promkes.kemkes.go.id/panduan-penggunaan-desa-untukbidang-kesehatan2018.

[12] E.Martha,. "Qualitative Research Method for Health Research, 2017", Rajagrafindo Persada, Jakarta.2017.

[13] Jember Gov."'Regional Medium Term Development Plan (RPJMD) 2016-2021". Jember,2016.

[14] Jember Gov.” Jember COVID-19 Budget of Rp. 479.4 Billion, Here's an Explanation". Source: http://www.jemberkab.go.id/anggaranCOVID-19-jember-sebesar-rp-4794-miliar-berikut-penjelasannya/ (access June 2020). 2020.

[15] S. Wahyunik,. "East Java Regional Minimum Wage 2020 Set, Jember Rp 2.3 Million, Up Rp 184 Thousand Compared to The Previous Year".In press. $2019 . \quad$ Source: https://jatim.tribunnews.com/2019/11/20/umk-jatim-2020ditetapkan-jember-rp-23-juta-naik-rp-184-ribu-dibanding-tahunsebelumnya (access Augt 2020). 2019. 